Catharine Coleborne - 9781784996710 Downloaded from manchesterhive.com at $\odot 4 / 26 / 2023$ 10:47: ๑๑AM via free access 


\section{STUDIES IN
IMPERIALISM}

General editor: Andrew S. Thompson

Founding editor: John M. MacKenzie

When the 'Studies in Imperialism' series was founded more than thirty years ago, emphasis was laid upon the conviction that 'imperialism as a cultural phenomenon had as significant an effect on the dominant as on the subordinate societies'. With well over a hundred titles now published, this remains the prime concern of the series. Cross-disciplinary work has indeed appeared covering the full spectrum of cultural phenomena, as well as examining aspects of gender and sex, frontiers and law, science and the environment, language and literature, migration and patriotic societies, and much else. Moreover, the series has always wished to present comparative work on European and American imperialism, and particularly welcomes the submission of books in these areas. The fascination with imperialism, in all its aspects, shows no sign of abating, and this series will continue to lead the way in encouraging the widest possible range of studies in the field. 'Studies in Imperialism' is fully organic in its development, always seeking to be at the cutting edge, responding to the latest interests of scholars and the needs of this ever-expanding area of scholarship.

\section{Insanity, identity and empire}

\section{MANCHESTER} 1824

Manchester University Press 


\section{SELECTED TITLES AVAILABLE IN THE SERIES}

\section{WRITING IMPERIAL HISTORIES}

ed. Andrew S. Thompson

MUSEUMS AND EMPIRE

Natural history, human cultures and colonial identities

John M. MacKenzie

MISSIONARY FAMILIES

Race, gender and generation on the spiritual frontier

Emily J. Manktelow

THE COLONISATION OF TIME

Ritual, routine and resistance in the British Empire

Giordano Nanni

BRITISH CULTURE AND THE END OF EMPIRE

ed. Stuart Ward

SCIENCE, RACE RELATIONS AND RESISTANCE

Britain, 1870-1914

Douglas A. Lorimer

GENTEEL WOMEN

Empire and domestic material culture, 1840-1910

Dianne Lawrence

EUROPEAN EMPIRES AND THE PEOPLE

Popular responses to imperialism in France, Britain, the Netherlands,

Belgium, Germany and Italy

ed. John M. MacKenzie

SCIENCE AND SOCIETY IN SOUTHERN AFRICA

ed. Saul Dubow 


\section{Insanity, identity and empire}

IMMIGRANTS AND INSTITUTIONAL CONFINEMENT IN AUSTRALIA AND NEW ZEALAND, I 873-I9I O

Catharine Coleborne

MANCHESTER

UNIVERSITY PRESS 
Copyright (C) Catharine Coleborne 2015

The right of Catharine Coleborne to be identified as the author of this work has been asserted by her in accordance with the Copyright, Designs and Patents Act 1988.

Published by MANCHESTER UNIVERSITY PRESS

ALTRINCHAM STREET, MANCHESTER M1 7JA

www.manchesteruniversitypress.co.uk

British Library Cataloguing-in-Publication Data

A catalogue record for this book is available from the British Library

Library of Congress Cataloging-in-Publication Data applied for

ISBN 9780719087240 hardback

First published 2015

The publisher has no responsibility for the persistence or accuracy of URLs for any external or third-party internet websites referred to in this book, and does not guarantee that any content on such websites is, or will remain, accurate or appropriate.

Typeset by

Servis Filmsetting Ltd, Stockport Cheshire 